\title{
Tolerance of honey bee adults and larvae toward tyrothricin peptides derived from Brevibacillus parabrevis
}

\author{
J. Arnold Vosloo ${ }^{1}$, Hannes Beims ${ }^{2,3}$, Michael H. Allsopp ${ }^{4}$, Wilma van Rensburg ${ }^{1}$, \\ Werner von der $\mathrm{OHE}^{3}$, Michael STEINERT ${ }^{2}$, Marina RAUTENBACH ${ }^{1}$ \\ ${ }^{1}$ BIOPEP Peptide Group, Department of Biochemistry, Stellenbosch University, Private Bag X1, Matieland, Stellenbosch \\ 7600 , South Africa \\ ${ }^{2}$ Institut für Mikrobiologie, Technische Universität Braunschweig, Braunschweig, Germany \\ ${ }^{3}$ Lower Saxony State Office for Consumer Protection and Food Safety, Institute for Apiculture, Celle, Germany \\ ${ }^{4}$ Honey Bee Research Section, Agricultural Research Council-Plant Protection Research Institute, Private Bag X5017, \\ Stellenbosch, South Africa
}

Received 11 November 2016 - Revised 22 May 2017 - Accepted 28 June 2017

\begin{abstract}
Tyrothricin is a peptide complex containing the linear gramicidins and cyclic tyrocidines. The tyrocidines have potent activity against fungal plant pathogens. As these peptides have possible agricultural applications, their toxicity was evaluated toward honey bee adults and larvae. Tyrothricin formulated in sucrose was non-toxic to caged adult honey bees at up to $1.5 \mathrm{~g} / \mathrm{L}$ over 48 -h exposure, which is 100 - to 200 -fold higher than the amount needed to eradicate high fungal loads $\left(2 \times 10^{4}\right.$ spores $\left./ \mathrm{mL}\right)$. Moreover, tyrothricin and the tyrocidines displayed potent in vitro activity toward foulbrood causing pathogens (Paenibacillus larvae, Melissococcus plutonius, Paenibacillus alvei) in honey bee larvae. In vivo tyrothricin or tyrocidine treatment delayed infection onset, indicating potential for curing. Tyrothricin was also found to be non-toxic with possible protective action in a semi-field trial on young bees released into hives, indicating the relative safety of the application of these antimicrobial peptides in an agricultural setting.
\end{abstract}

tyrothricin / tyrocidine / antimicrobial peptides / agriculture / antifungal / honey bee tolerance

\section{INTRODUCTION}

The use of honey bees as the principal pollinators in commercial agriculture results in their exposure to pesticides, thereby threatening the honey bee population (Krupke et al. 2012) especially because chronic exposure increases their susceptibility toward pathogens (Pettis et al. 2013). The combination of increased resistance toward many

Electronic supplementary material The online version of this article (doi:10.1007/s13592-017-0528-0) contains supplementary material, which is available to authorized users.

Corresponding author: J. Arnold Vosloo, arnie@sun.ac.za;

M. Rautenbach,mra@sun.ac.za

Manuscript editor: Bernd Grünewald antimicrobial agents, alongside awareness of the negative impact of chemical control agents has driven the impetus for alternate, so-called greenbiocides (de Souza et al. 2015; Mnif and Ghribi 2015; Montesinos 2007).

Antimicrobial peptides (AMPs) may be such a solution as they are ubiquitously present throughout the prokaryotic and eukaryotic kingdoms (Guimarães et al. 2016; Rautenbach et al. 2016a; Wang et al. 2016), and therefore are often considered the natural way of maintaining a balanced ecology (Nautiyal and Dion 2008). Microorganisms have been used as bio-control agents in agricultural applications to protect plants from numerous fungal pathogens (Compant et al. 2005; Nautiyal and Dion 2008; Pusey 1989), particularly those of the Bacillus spp. which produce the cyclic AMPs such as iturin (Pusey and Wilson 
1984; Pusey 1989), iturin A and surfactin (Asaka and Shoda 1996), as well as gramicidin S (Chandel et al. 2010; Che et al. 2015). Some of these produced cyclic AMPs which play a role in plant protection additionally display insecticidal activity, predominantly among these are the socalled lipopeptide biosurfactants which are utilised to further benefit plant production (Ghribi et al. 2012; Mnif et al. 2013). The latter includes surfactin which is insecticidal toward adult and larvae of the fruit fly Drosophila melanogaster, in contrast to coproduced iturin which shows no activity (Assie et al. 2002). Insecticidal activity has also been reported toward mosquito larvae by surfactin and iturin (Das and Mukherjee 2006) and gramicidin S, but not for the linear gramicidins that are found in tyrothricin (Nickerson and Schnell 1983).

Rautenbach et al. $(2013,2015)$ have initiated the use of the naturally produced tyrothricin (Tcn) peptide complex to treat plants in agricultural applications. These initial pilot studies demonstrate increased longevity of cut flowers in vases containing Ten solution, as well as survival of woody plant grafts and cuttings which were previously immersed in a Tcn solution of $<50 \mathrm{mg} / \mathrm{L}$. Both the cyclic tyrocidines (Trcs) and analogues, as well as the linear gramicidins (refer to Tang et al. (1992) for the primary structures), constitute the Tcn complex which is extracted from the biomass of the soil bacterium Brevibacillus parabrevis (Dubos and Hotchkiss 1941; Dubos 1939; Hotchkiss and Dubos 1941). The antimicrobial activity of the linear gramicidins is particularly effective toward Gram-positive bacteria, involving the destruction of the cell membrane (Andersen 1984; Hotchkiss and Dubos 1941). Including the ability to target Gram-positive bacteria (Dubos and Hotchkiss 1941; Spathelf and Rautenbach 2009), the tyrocidines and analogues have been shown to display potent activity toward agronomically relevant fungal pathogens (Rautenbach et al. 2016b; Troskie et al. 2014a), as well as having an application in plant protection (Rautenbach et al. 2013, 2015).

In order to consider the use of Tcn peptides in agriculture, knowledge of their influence on nontarget, beneficial organisms such as honey bees is essential. The potential of these natural AMPs can then also be evaluated to target honey bee pathogens. Antibiotics have been used in beekeeping since the 1950s with oxytetracycline being used for bacterial brood diseases including American and European Foulbrood (Reybroeck et al. 2012; Spivak 2000; Oldroyd et al. 1989). The emergence of resistance toward tetracyclines in Paenibacillus larvae (Evans 2003) has resulted in the approval of the macrolide antibiotic tylosin to treat infected colonies (Elzen et al. 2002). Residues of these compounds in honey remain a serious concern to their use, particularly in Europe (EC-European Commission 2010; Reybroeck et al. 2012).

The Tcn peptides have been proposed to work via a rapid membranolytic mode of action (Andersen 1984; Liou et al. 2015; Spathelf and Rautenbach 2009). The Tcn peptides have been safely utilised over more than 70 years when applied topically or when taken orally in mammals (Lang and Staiger 2016; Robinson and Molitor 1942; StaussGrabo et al. 2014). To our knowledge, only a single report exists reporting the maximum tolerable dosage of a highly purified tyrocidine analogue to treat the nematode Caenorhabditis elegans in a medical infection model of the yeast Candida albicans (Troskie et al. 2014b). We report here the first extensive evaluation of the toxicity of the Tcn peptides toward insects, and more specifically, honey bees and their larvae. Once toxicity parameters were established, we did an exploratory study on the potential of Ten peptides to combat pathogens affecting honey bee larvae in the hive.

\section{METHODS}

\subsection{Acute oral tolerance of adult honey bees toward Ten}

Oral toxicity studies were performed using adult Cape honey bees, Apis mellifera capensis, at the Agricultural Research Council Plant Protection Research Institute, Vredenburg Research Centre (Stellenbosch, South Africa). A culture-produced extract, denoted as Tcn, was prepared and analysed according to Vosloo et al. (2013) (refer to 
Suppl. Materials). The oral toxicity of Ten to honey bees was evaluated using an adaptation of the methodology described in the OECD/ OCDE Test Guideline (TG) 213 (OECD 1998). A brood frame was removed from a queen-right colony and maintained at 35 $\pm 2{ }^{\circ} \mathrm{C}$ and $50 \%$ relative humidity. Emerged worker bees were subsequently marked every $24 \mathrm{~h}$ using coloured markers (Posca Pens, Japan) and returned to the hive. Marked mixed aged bees less than 10 days old were re-captured and ten bees were placed in wooden Liebefeld cages and fed a feeding solution $(50 \%(\mathrm{~m} / \mathrm{v})$ sucrose in water) in a glass tube. Bees were acclimatised to experimental conditions for $24 \mathrm{~h}$, after which the feeders were removed for $2 \mathrm{~h}$. Temperature and humidity were recorded using Thermochron DS1922L i-Buttons from Maxim Integrated Products (San Jose, USA) and maintained at $27 \pm 2{ }^{\circ} \mathrm{C}$ and $52 \pm 5 \%$ relative humidity.

At least four cages were randomly assigned to each of the experimental groups. Tcn stock solutions were prepared in distilled dimethyl formamide (DMF) and then diluted to contain $1 \%(v / v)$ DMF and between 1.5 and $0.05 \mathrm{mg} /$ $\mathrm{mL}$ Tcn in feeding solution. Three control groups received only feeding solution or together with $1 \%(v / v)$ DMF (dosing vehicle) and a positive control group received $35 \mu \mathrm{g} / \mathrm{mL}$ of the reference chemical insecticide dimethoate (DiM), in feeding solution and dosing vehicle. Bees were subsequently fed a diet of only the mentioned concentration range of Tcn, together with the respective controls, for up to $72 \mathrm{~h}$, barring the DiM control. In the latter, exposure was limited to $6 \mathrm{~h}$ after which any unconsumed feed was removed and a fresh feeder with feeding solution was then replaced. In all the experimental groups, the volume feed consumed and mortality was recorded after 4 and $6 \mathrm{~h}$, then every $24 \mathrm{~h}$ until a maximum of $72 \mathrm{~h}$. Bees which displayed any sublethal effects, including lack of mobility, were recorded together with mortality and removed at each observation period. Mortalities were adjusted relative to those observed in the uninfected controls using Abbott's correction (Abbott 1925).

\subsection{Delayed toxicity testing and survival in hives after Tcn exposure}

Freshly emerged worker honey bees from three different hives were marked and placed in the Liebefeld cages, with no more than 300 bees per cage. By means of three $20-\mathrm{mL}$ glass feeders per cage, bees from each of the different hives were fed a diet composed of $50 \%$ sucrose and $1 \%$ DMF (control), or $50 \%$ sucrose and $1.5 \mathrm{mg} / \mathrm{mL}$ Tcn containing $1 \%$ DMF for $48 \mathrm{~h}$. Mortality, sublethal effects and volume consumed were recorded for the first $6 \mathrm{~h}$ and then at 24, 48 and $72 \mathrm{~h}$. Bees of the control and experimental groups were then lightly sprayed with a water/honey/alcohol solution and returned to the hive from which the respective brood frames originated. Bees were then counted after 3 days and weekly thereafter until 28 days. Sublethal effects were monitored through collection of a sample of ten bees from each experimental group at each counting for weighing and dissection and the total number of bees adjusted accordingly, until 28 days when all the remaining marked bees where collected. These bees were stored in airtight containers at $-20{ }^{\circ} \mathrm{C}$ for dissection and analysis.

\subsection{Oral tolerance of bee larvae toward Ten and Tre mixture}

Carniolan honey bee, A. mellifera carnica, L1 larvae $<30 \mathrm{~h}$ old were obtained from hives at the Technische Universität Braunschweig (Braunschweig, Germany) using queen bees that were bred at the Lower Saxony State Office for Consumer Protection and Food Safety, Institute for Apiculture (Celle, Germany) and reared as described by Lüken et al. (2012). The purified Trc mixture (without gramicidins) was prepared from commercial Ten (Sigma-Aldrich, Steinheim, Germany) as described by Hotchkiss and Dubos (1941).

The in vivo toxicity of Tre mixture and cultureprepared Tcn toward bee larvae was tested according to the OECD/OCDE TG 237 (OECD 2013). Larvae were collected from three different, unrelated colonies of A. mellifera carnica (OECD 2013). Aliquoted dry masses of tyrocidine and Tcn peptide formulations were dissolved in 
DMF prior to dilution in Diet C (OECD 2013). Larvae were fed $33 \mu \mathrm{L}$ of the prepared Diet $\mathrm{C}$ on day 4 containing concentrations of $6.17,18.5$, $55.6,167$ or $500 \mu \mathrm{g} / \mathrm{mL}$ of tyrocidine or Tcn. This equated to a single exposure of 0.204 , $0.611,1.83,5.5$ or $16.5 \mu \mathrm{g} /$ larva. Controls were performed for natural mortality (diets without peptide and solvent), $0.76 \%(v / v)$ DMF solvent and DiM at a concentration of $267 \mu \mathrm{g} / \mathrm{mL}$, thus $8.8 \mu \mathrm{g} /$ larva. Three replicates containing 12 larvae were repeated for each colony for each of the respective test conditions. The development of the larvae was assessed and any sublethal effects were recorded as well as the mortality up to day 7 , after which the tests were terminated (OECD 2013). Mortalities were adjusted relative to those observed in the uninfected controls using Abbott's correction (Abbott 1925).

\subsection{Preparation of peptide formulations for antimicrobial activity assays}

Analytically weighed aliquots of the dried Trc mixture or Tcn peptide formulations were dissolved in $75 \%$ ethanol/water $(v / v)$. These were subsequently diluted using sterilised water to $1.00 \mathrm{mg} / \mathrm{mL}$ in $15 \%$ ethanol. Peptide formulations were prepared in an eight-step doubling dilution series prior to tenfold dilution in the antimicrobial assays to a final solvent concentration of $1.5 \%$ ethanol.

\subsection{Antifungal activity assays toward Aspergillus fumigatus}

Spores of the fungi A. fumigatus ATCC 204305 were obtained from freezer stocks and cultured using normal sterile techniques on potato dextrose agar plates for 3 weeks. A previously described microtiter broth dilution method (Broekaert et al. 1990) was used to test the antimicrobial activity, as adapted by Troskie et al. (2012). A final spore concentration of $2 \times 10^{4}$ spores $/ \mathrm{mL}$ was obtained in half strength potato dextrose broth together with the peptide formulations applied in triplicate per assay. Plates were incubated at $25{ }^{\circ} \mathrm{C}$ for $16 \mathrm{~h}$ prior to the $\mathrm{OD}_{595}$ measurement in a microplate reader $\left(\operatorname{BioRad}^{\mathrm{TM}}\right)$.

\subsection{Antibacterial activity assays toward foulbrood agents and associated pathogens}

The identity and origin of all microorganisms used in the study is summarised in Table SI (refer to Suppl. Materials). Antimicrobial activity assays were performed against all four known genotypes of P. larvae (ERIC I, DSM 7030; ERIC II, DSM 25430; ERIC III, LMG 16252; ERIC IV, LMG 16247) (Genersch et al. 2006), the causative agent of American Foulbrood, and against Melissococcus plutonius, the causative agent of European Foulbrood, as well as its associated secondary invaders, Paenibacillus alvei and Enterococcus faecalis (Forsgren 2010).

Single colonies were obtained from freezer stocks and grown on Columbia sheep blood agar for $16 \mathrm{~h}$ at $37^{\circ} \mathrm{C}$ and $5 \%(v / v) \mathrm{CO}_{2}$. Antimicrobial activity assays in brain heart infusion (BHI) broth $(3.7 \%(\mathrm{~m} / \mathrm{v}) \mathrm{BHI}, 0.3 \%(\mathrm{~m} / \mathrm{v})$ yeast extract) were performed in triplicate by means of the microtiter broth dilution method described by $\mathrm{Du}$ Toit and Rautenbach (2000) and Lehrer et al. (1991). However, M. plutonius was cultivated on basal medium plates and liquid media $(1.0 \%(\mathrm{~m} / \mathrm{v})$ yeast extract, $1.0 \%(\mathrm{~m} / \mathrm{v})$ glucose, $1.0 \%(\mathrm{~m} / \mathrm{v})$ starch, $0.03(\mathrm{~m} / \mathrm{v})$ L-cystein and $0.1 \mathrm{M} \mathrm{KH}_{2} \mathrm{PO}_{4}$, $\mathrm{pH}$ adjusted to 6.6 using $\mathrm{KOH} ; 0.2 \%(\mathrm{~m} / \mathrm{v})$ agar added for plates) under anaerobic conditions (Bailey 1957). Plates were incubated at $37{ }^{\circ} \mathrm{C}$ for $16 \mathrm{~h}$ prior to the $\mathrm{OD}_{595}$ measurement in a microplate reader (Thermo Fisher, Varioskan Flash).

\subsection{Curing assays of Paenibacillus larvae- infected bee larvae}

Rearing of bee larvae was performed as previously described (Beims et al. 2015; Lüken et al. 2012). At day 1, 500 spores of P. larvae ERIC I (DSM 7030) or ERIC II (DSM 25430) were added to Diet A (OECD 2013) to infect the larvae (Beims et al. 2015), barring those which served as uninfected controls. Peptide formulations (Tcn at $55.6 \mu \mathrm{g} / \mathrm{mL}$ $(1.83 \mu \mathrm{g} /$ larva $)$ and Trc mixture at $18.5 \mu \mathrm{g} / \mathrm{mL}$ $(0.611 \mu \mathrm{g} /$ larva $))$ were fed to cure infected larvae on day 4 in Diet C (OECD 2013). Infected 
control larvae were fed Diet $\mathrm{C}$ without any additives. Three different, unrelated colonies were used in replicates of 36 larvae each. These were inspected and mortality recorded for 14-day post-infection. Dead individuals were homogenised and plated out on blood agar in order to confirm killing by $P$. larvae using P. larvae-specific 16S rRNA-PCR detection (Govan et al. 1999). Mortalities were adjusted relative to those observed in the uninfected controls using Abbott's correction (Abbott 1925) and plotted against time for comparative analysis (Beims et al. 2015).

\subsection{Data analysis}

GraphPad Prism® 4.03 (GraphPad Software, San Diego, USA) was used to plot all graphs, as well as perform all statistical analysis using twoway repeated measures ANOVA with Bonferroni's multiple comparison post-test. Antimicrobial activity parameters were determined from these plots including the minimum inhibitory concentration ( $\mathrm{MIC}$ or $\mathrm{IC}_{\max }$, lowest concentration used where no growth is graphically observed) (Rautenbach et al. 2006).

\section{RESULTS}

\subsection{In vivo tolerance of adult honey bees toward Ten}

The acute oral toxicity of Tcn was evaluated toward adult bees and no toxicity was observed in preliminary experiments when bees were exposed to the test compound for a period of up to $6 \mathrm{~h}$, having consumed $44.70 \pm 1.98 \mu \mathrm{g}$ of Tcn at the highest concentration of $2.5 \mathrm{mg} / \mathrm{mL}$ (data not shown).

To increase the amount of Tcn consumed, bees were fed a diet of $50 \%(\mathrm{~m} / \mathrm{v})$ sucrose and various Tcn concentrations for up to $72 \mathrm{~h}$ (Figure 1). In conformation of the sensitivity of our experimental conditions, after the $6 \mathrm{~h}$ of exposure, bees consumed $0.48 \pm 0.04 \mu \mathrm{g}$ DiM (data not shown) and near $100 \%$ mortality was observed within $24 \mathrm{~h}$ (Figure 1c). The mortality did not exceed $10 \%$ in the controls fed only $50 \%(\mathrm{~m} / \mathrm{v})$ sucrose,
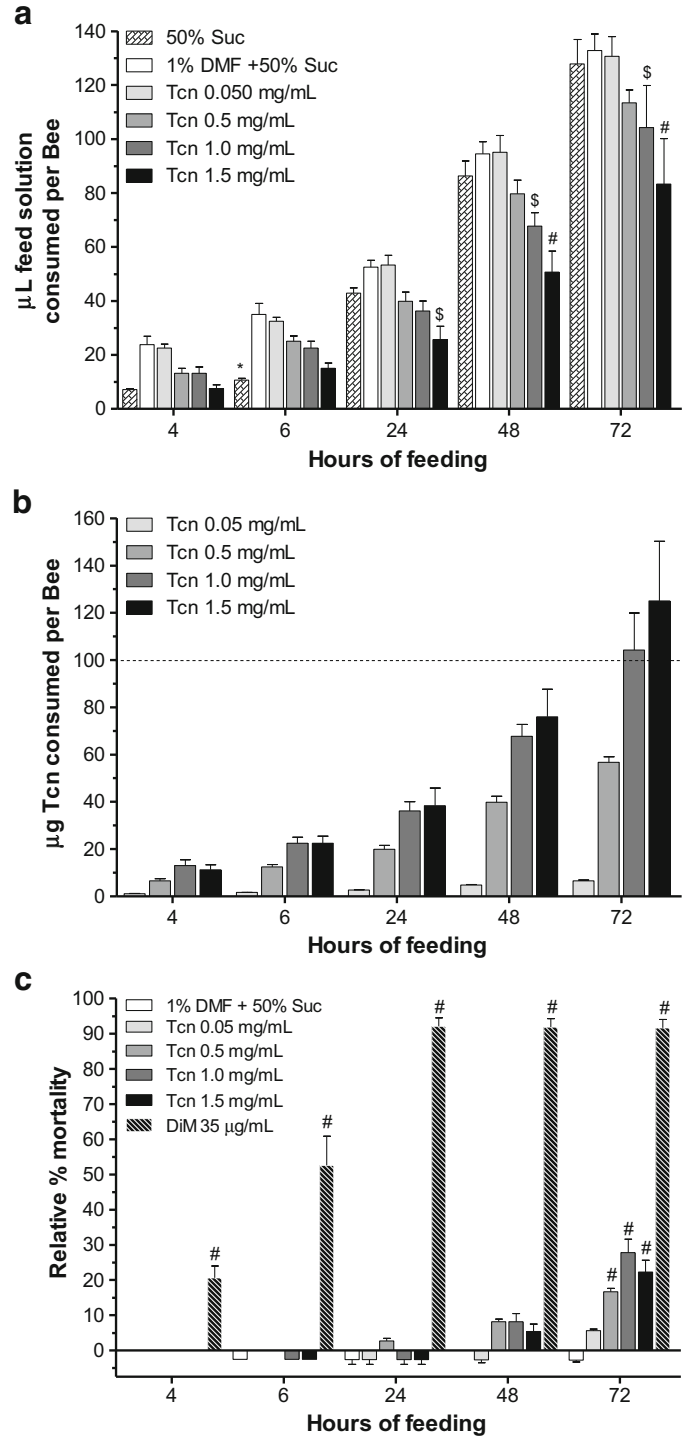

Figure 1. Consumption of Ten by adult Cape honey bees relative to the vehicle $50 \%$ sucrose (Suc) containing $1 \%$ DMF and positive control containing $35 \mu \mathrm{g} / \mathrm{mL}$ DiM. Panel a shows the comparison of the volume consumed per bee in the different feeding solutions, degrees of freedom (Df) 20; $\mathbf{b}$ the amount of Tcn in $\mu \mathrm{g}$ consumed per bee in each of the respective Tcncontaining feeding solutions and $\mathbf{c}$ the relative percentage mortality of bees observed in each of the different feeding solutions over the 72-h feeding period corrected relative to the natural mortality in $50 \%$ sucrose using Abbott's correction, Df 24. Each bar is the mean of four determinations with standard error of the mean (SEM) with significant differences relative to $1 \%$ DMF depicted as ${ }^{\#} P<0.001 ;{ }^{\$} P<0.01 ; * P<0.05$. 
as well as those with a control diet also containing $1 \%$ DMF.

A maximum concentration of $\mathrm{Tcn}$ at $1.5 \mathrm{mg} / \mathrm{mL}$ was used to prevent the influence of Tcn precipitation out of the feeding solution over the extended feeding period. A reduction in feed volume consumed was observed in all the Tcn treatments barring the lowest concentration of $0.05 \mathrm{mg} / \mathrm{mL}$ (Figure 1a). After $48 \mathrm{~h}$ of consuming a diet of only sucrose and peptide, with $76 \mu \mathrm{g}$ consumed per bee at $1.5 \mathrm{mg} / \mathrm{mL}$ Tcn (Figure 1b), virtually no toxicity was observed (Figure 1c). The bees consumed $1.2 \mu \mathrm{g} / \mathrm{mg}$ body mass (66 $\mathrm{mg}$ average bee mass) at $48 \mathrm{~h}$ before any significant toxicity was observed at $72 \mathrm{~h}$. At $72 \mathrm{~h}$, an increase in mortality in all the conditions tested was observed, barring the 1\% DMF control. At the 1.0 and $1.5 \mathrm{mg} / \mathrm{mL}$ Tcn concentrations, a mortality of $\pm 25 \%$ was reached, representing in excess of $100 \mu \mathrm{g}$ of Tcn consumed per bee (Figure 1b, c).

\subsection{Survival of young bees in hives after Ten exposure}

Having observed an increase in mortality after $48 \mathrm{~h}$ in honey bees fed solely a diet spiked with Tcn, this observed toxicity was analysed further in a semi-field trial application. Ten at $1.5 \mathrm{mg} / \mathrm{mL}$ was the highest concentration which could be maintained in the feeding solution over the extended feeding exposure to Tcn. After 2 days of caged feeding, no difference in survival was observed between the bees fed Tcn relative to the dosing vehicle control (survival $>90 \%$ ) (Figure 2).

After returning the young bees to their hives of origin, retrieval of the Tcn-fed group was 25-75\% greater than the control, being statistically significant for days 5 and 20 (Figure 2). Activity level and behaviour of marked bees returned to the hive did not differ from those in the hive. Sublethal effects were monitored indirectly by age-related sampling; subsequent dissection of these bees revealed no definitive difference between the Tcnfed bees and controls on day 2 prior to being

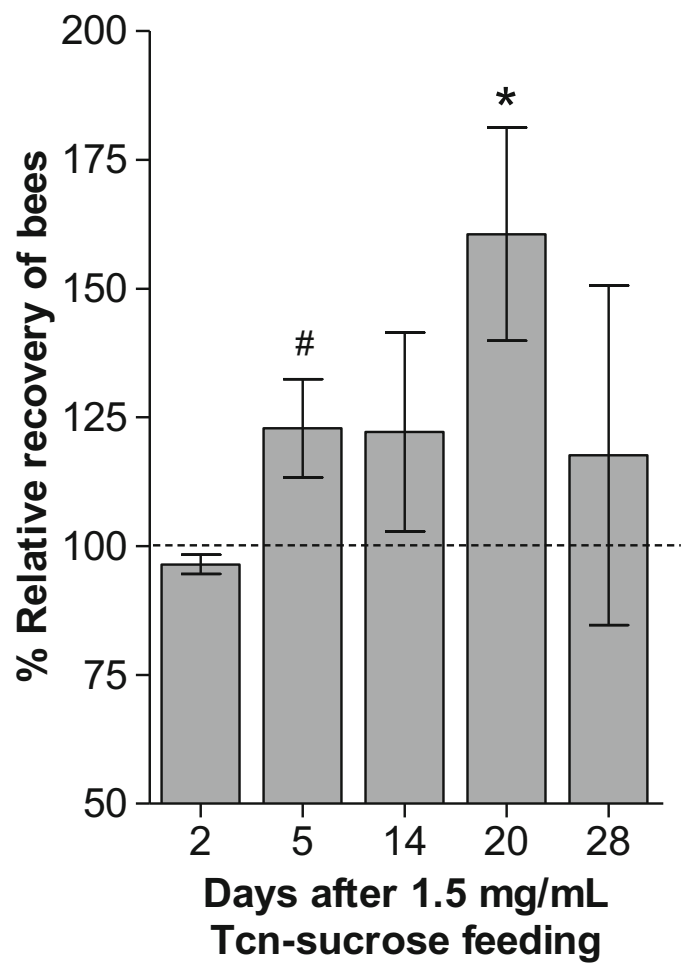

Figure 2. Comparison of the retrieval of Cape honey bees fed $1.5 \mathrm{mg} / \mathrm{mL}$ Tcn dissolved in $50 \%$ sucrose feeding solution relative to the $1 \%$ DMF control for 2 days and then returned to their hives of origin. Each bar represents the percent average retrieval of bees in six hives compared to the control with the error bar representing the $\mathrm{SEM}^{\#} P<0.001 ;{ }^{*} P<0.05$; Df 4 .

returned to their hives or when subsequently retrieved from the hives (data not shown).

\subsection{Tolerance of bee larvae toward the Trc mixture and Ten}

As larvae are fed by the adult bees that may have ingested Tcn or Trc mixture, the honey bee larva tolerance toward these peptides was assessed. The natural mortality of the larvae only fed the feeding solution was consistently below $10 \%$ (Figure 3). A concentration of $55.6 \mu \mathrm{g} / \mathrm{mL}(1.8 \mu \mathrm{g} /$ larva $)$ of $\mathrm{Tcn}$ and $18.5 \mu \mathrm{g} / \mathrm{mL}(0.61 \mu \mathrm{g} /$ larva $)$ of the high-purity Trc mixture were found to be the highest 


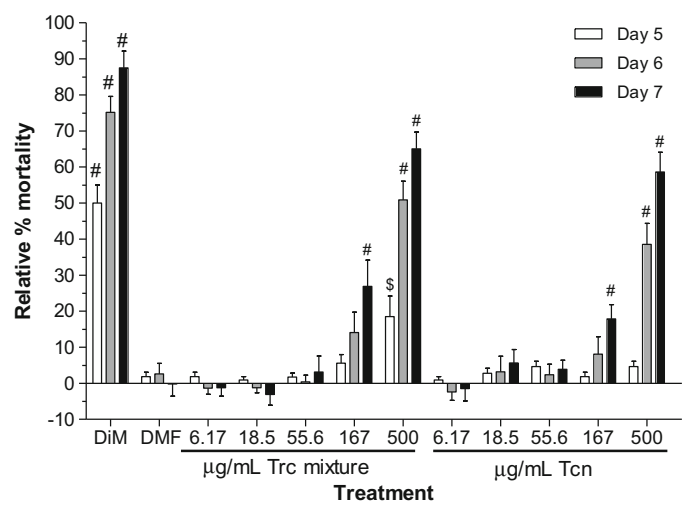

Figure 3. Comparison of the relative percentage mortality of Apis mellifera carnica honey bee larvae after a single exposure to varied concentrations of Trc mixture or Tcn at day 4. Each bar is the mean of nine determinations with SEM relative to mortality after exposure to $0.76 \%$ DMF feeding vehicle was compared to each of the respective treatments at days 5, 6 and $7{ }^{\#} P<0.001$; $* P<0.05 ;$ Df, 24.

concentration the bee larvae could tolerate without any toxicity (Figure 3).

\subsection{Activity of peptide formulations toward honey bee pathogens causing foulbrood}

The Tcn and Trc peptide mixtures had potent activity toward the opportunistic A. fumigatus (Table I), one of the causative agents of stonebrood disease or aspergillosis in honey bee larvae (Foley et al. 2012). It was questioned whether these peptides would have any potential to inhibit bacterial pathogens affecting honey bee larvae. The in vitro activity of the Tcn and Trc mixture was subsequently evaluated toward a range of bee pathogens associated with foulbrood (Table I).

All of the different strains of $P$. larvae were sensitive to Tcn; ERIC I isolate 25 and 145, as well as ERIC II isolate 1 were less sensitive (Table I). M. plutonius, P. alvei and E. faecalis also showed high sensitivity toward the peptide formulation (Table I). The two peptide formulations showed similar activity, thereby negating the influence of the linear gramicidins in the Tcn formulation.

\subsection{Assessment of the potential of Ten and tyrocidines to treat infected bee larvae}

Having established the peptide toxicity parameters toward honey bee larvae, it was investigated if the promising in vitro activity toward $P$. larvae could be emulated in vivo. Larvae were infected with spores of either $P$. larvae reference strains ERIC I (DSM 7030) or ERIC II (DSM 25430) at day 1 and treated with the Tcn or Trc mixture on day 4 at 55.6 or $18.5 \mu \mathrm{g} / \mathrm{mL}$, respectively (Figure 4). The mortality of the uninfected controls was below an average of $10 \%$ until day 9 where after an increase in mortality to $30 \%$ was observed at day 15 . This mortality was adjusted for using Abbott's correction (Abbott 1925).

It was apparent that the in vivo antimicrobial activity of Tcn toward $P$. larvae was not as high as had been observed in vitro. Tcn, however, slowed the rate at which the infection progressed significantly in both strains, but was more effective at slowing down infection of ERIC II (DSM 25430) (Figure 4). This was particularly evident at day 5 when there was only about $40 \%$ survival in the untreated group with Eric II infection and $>85 \%$ survival for the Tcn treatment and $>60 \%$ for Trc mixture treatment (Figure 4). However, our single delayed treatment regime of Tcn or Trc mixture had no long-term therapeutic or curative effect and a final mortality similar to the infection controls.

\section{DISCUSSION AND CONCLUSIONS}

The culture extracts of Tcn, which were to be used in the proposed agricultural applications, displayed very low toxicity toward adult honey bees. Using concentrations of 100-200 times the MIC observed toward fungal pathogens relevant to the agricultural industry (Troskie et al. 2014a), including the bee pathogen A. fumigatus (Table I), no toxicity was observed toward the bees fed for the conventional 6-h toxicity testing (OECD 1998). Up to $1.5 \mathrm{mg} / \mathrm{mL}$ of Tcn were fed to bees; however, consumption of such high amounts of Tcn would be unachievable in a field application in light of the low solubility of Tcn. A reduction in feed volume consumed (Figure 1a) illustrates further how 
Table I. Antimicrobial activity of Ten and Trc mixture toward honey bee pathogens causing foulbrood infections and associated secondary invaders

\begin{tabular}{|c|c|c|c|}
\hline \multirow[b]{2}{*}{ Organism } & \multirow[b]{2}{*}{ Pathogenic strain } & \multicolumn{2}{|c|}{$\operatorname{MIC}(\mu \mathrm{g} / \mathrm{mL}) \pm \mathrm{SEM}$} \\
\hline & & Ten & Trc mixture \\
\hline Aspergillus fumigatus & ATCC $204305(n=37)$ & $12 \pm 0.5$ & $8.9 \pm 1.3$ \\
\hline \multirow[t]{15}{*}{ Paenibacillus larvae } & ERIC I, DSM $7030(n=2)$ & $6.3 \pm 0$ & $3.1 \pm 0$ \\
\hline & ERIC II, DSM $25430(n=3)$ & $2.7 \pm 1.8$ & $3.1 \pm 1.6$ \\
\hline & ERIC III, LMG $16252(n=3)$ & $2.1 \pm 0.5$ & $3.1 \pm 0$ \\
\hline & ERIC IV, LMG $16247(n=3)$ & $7.3 \pm 2.8$ & $5.2 \pm 1.0$ \\
\hline & ERIC I, Isolate $11(n=3)$ & $1.2 \pm 0.2$ & $2.6 \pm 0.5$ \\
\hline & ERIC I, Isolate $15(n=3)$ & $<<0.78$ & $1.6 \pm 0$ \\
\hline & ERIC I, Isolate $24(n=2)$ & $2.3 \pm 2.0$ & $1.3 \pm 0.9$ \\
\hline & ERIC I, Isolate $25(n=3)$ & $29 \pm 11$ & $15 \pm 5.5$ \\
\hline & ERIC I, Isolate $138(n=3)$ & $<<0.78$ & $<<0.78$ \\
\hline & ERIC I, Isolate $145(n=3)$ & $22 \pm 1.7$ & $17 \pm 4.2$ \\
\hline & ERIC II, Isolate $1(n=3)$ & $25 \pm 0$ & $17 \pm 4.2$ \\
\hline & ERIC II, Isolate $3(n=2)$ & $3.1 \pm 0$ & $3.1 \pm 0$ \\
\hline & ERIC II, Isolate $6(n=3)$ & $1.3 \pm 0.4$ & $3.1 \pm 0$ \\
\hline & ERIC II, Isolate $7(n=3)$ & $3.13 \pm 0$ & $3.1 \pm 0$ \\
\hline & ERIC II, Isolate $17(n=3)$ & $<<0.78$ & $1.6 \pm 0$ \\
\hline Melissococcus plutonius & LMG $20360(n=3)$ & $13 \pm 0$ & $6.3 \pm 0$ \\
\hline Paenibacillus alvei & $\operatorname{DSM} 29(n=2)$ & $1.6 \pm 0$ & $1.6 \pm 0$ \\
\hline Enterococcus faecalis & DSM $20376(n=3)$ & $8.3 \pm 2.1$ & $10 \pm 2.1$ \\
\hline
\end{tabular}

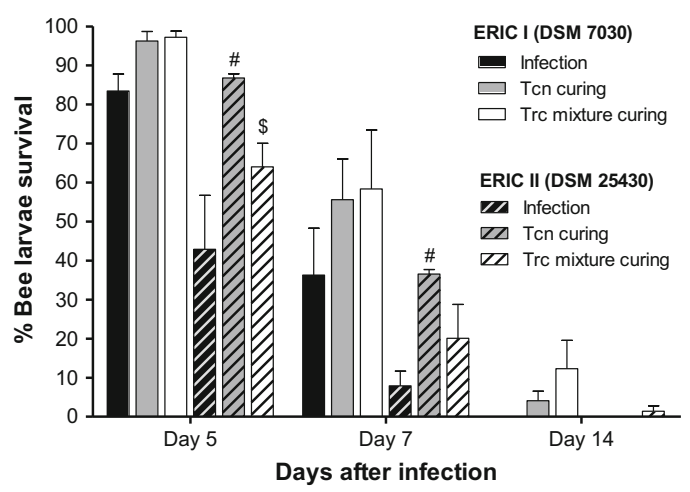

Figure 4. Curing assays of Apis mellifera carnica honey bee larvae after a single exposure of Tcn at $55.6 \mu \mathrm{g} /$ $\mathrm{mL}(1.83 \mu \mathrm{g} /$ larva) on day 4 after being pre-exposed to Paenibacillus larvae spores on day 1 of either the ERIC I (DSM 7030) or ERIC II (DSM 25430) strain. The relative mortality in the infection controls after exposure to $0.76 \%$ DMF feeding vehicle was compared to each of the respective treatments at days 5, 7 and $14\left({ }^{\#} P<0.001\right.$; ${ }^{\$} P<0.01$; Df 26). unlikely it would be for these high concentrations to be consumed by bees. After $48 \mathrm{~h}$ having consumed $76 \mu \mathrm{g} /$ bee at $1.5 \mathrm{mg} / \mathrm{mL}$ Tcn (Figure 1b), an amount of $1.2 \mathrm{~g} / \mathrm{kg}$ body mass was found to be non-toxic to bees. These data concur with those of numerous others in the literature reporting the relative safety of the oral consumption of Tcn in mammals (Kolmer and Rule 1946; Rammelkamp and Weinstein 1942). Oral dosages as high as $1.0 \mathrm{~g} / \mathrm{kg}$ body mass were not toxic to mice and rats (Robinson and Molitor 1942).

After $72 \mathrm{~h}$, when an amount of Ten well in excess of the 'limit test' amount of $100 \mu \mathrm{g}$ compound per bee (OECD 1998) was consumed, a mortality of only $\pm 25 \%$ was reached (Figure 1b, c). It was postulated that the increase in mortality may have arisen due to the inability of the bees to defecate, possibly as a result of confinement. This was confirmed in the semi-field trial as the recovery of Tcn-fed bees from the hives exceeded that 
of the control-fed bees (Figure 2). Dissection of bees fed $1.5 \mathrm{mg} / \mathrm{mL}$ Tcn for $48 \mathrm{~h}$ showed that no visual differences between the Tcn-fed bees and control-fed bees. Thus, even at such high concentrations, consumption of Tcn by adult bees was found to be safe and may even have been to an advantage to them.

In view of the safety of the application of Tcn toward adult bees, as well as the possible increased survival, it was speculated whether the spectrum of applications of the Tcn peptides could be expanded to protect honey bees from pathogens in their hives, particularly those affecting honey bee larvae, as it is at these earliest, brood developmental stages while still in the hive where honey bees are most sensitive to pathogens (Genersch 2010). Due to the protein nature of AMPs, their consumption poses no threat and consequently could be fed to bees at a preventative concentration without their residues in honey posing any risk.

The Tcn peptides displayed potent in vitro activity toward the causative agents of stonebrood disease A. fumigatus (Foley et al. 2012), different strains of $P$. larvae, the causative agents of both American Foulbrood (Genersch et al. 2006), M. plutonius, the causative agent of European Foulbrood in honey bees, as well as associated secondary invaders P. alvei and E. faecalis (Forsgren 2010) (Table I). A concentration of $55.6 \mu \mathrm{g} / \mathrm{mL}$ Tcn or $1.83 \mu \mathrm{g} /$ larva was found to be non-toxic (Figure 3). Using the latter concentration, treatment with Ten significantly slowed down the rate at which the infection progression. However, the promising in vitro antimicrobial activity toward $P$. larvae did not result in curing with the late treatment on day 4 after infection of the bee larvae (Figure 4). It is possible that earlier application of Tcn to the honey bee larvae would increase their survival, as opposed to the prescribed fourth day application (OECD 2013). Some investigators have suggested the most applicable target of $P$. larvae would be to prevent germination of the spores (AbelSantos 2015; Alvarez and Abel-Santos 2007). Earlier application of Tcn may be more effective at targeting the germinating spores within the first $12 \mathrm{~h}$ of the larvae's life cycle
(Crailsheim and Riessberger-Gallé 2001; Yue et al. 2008).

Only a single other report of the toxicity of the Tcn peptides toward non-mammals exists where a concentration of $6 \mu \mathrm{M}$ $(7.62 \mu \mathrm{g} / \mathrm{mL})$ of the purified tyrocidine A analogue was found to be the maximum tolerable concentration used in the successful treatment of $C$. albicans infections in the nematode Caenorhabditis elegance (Troskie et al. 2014b). Bee larvae were thus considerably more resilient to Tcn peptides than the nematodes. All the rest of the reports of treatment of infections using the Tcn peptides are limited to mammalian systems, primarily using mouse models. Oral administration of Tcn is reported to slow down Pneumococcus and Streptococcus (Dubos and Cattaneo 1939; Kolmer and Rule 1946) or have no therapeutic effect on Lactobacillus acidophilus (Weinstein and Rammelkamp 1941) infections.

Due to the hydrophobic nature of Tcn, these AMPs adhere very strongly to surfaces (Rautenbach and van Rensburg 2015). This adhesion would therefore further limit any exposure that may occur to larvae after application in a plant protective function. It is concluded that Ten has very low oral toxicity toward honey bees, and this low oral toxicity correlates to what was observed in mammals (Lang and Staiger 2016; Robinson and Molitor 1942; Stauss-Grabo et al. 2014). Moreover, as is the case with many other AMPs that are produced naturally by microorganisms in healthy soil and water bodies, these natural products are biodegraded to amino acids (Maeda et al. 1993; Moncla et al. 2011) which serve as nutrients to plants (Schobert et al. 1988). Tcn peptides are therefore extremely unlikely to cause an adverse effect toward bees when applied within an agricultural setting and would rather have a beneficial effect. The inhibitory activity toward bee pathogens and positive effects toward adult bees and their larvae opens the possibility of the future development of formulations containing Tcn or other AMPs to combat honey bee pathogens. 


\section{ACKNOWLEDGMENTS}

The reported work forms part of a research project, 'Natural antimicrobial peptides as green microbicides in agriculture', funded by the Green Fund, an environmental finance mechanism implemented by the Development Bank of Southern Africa (DBSA) on behalf of the Department of Environmental Affairs (DEA). Opinions expressed and conclusions arrived at are those of the authors and are not necessarily to be attributed to the Green Fund, DBSA or DEA.

\section{Author Contributions}

JAV, MHA and MR conceived the research and performed experiments on adult bees and fungi, WvR performed HPLC of tyrothricin and HB W vd O and MS designed and performed experiments on larvae and pathogens.

Tolérance des adultes et des larves d'abeille vis-à-vis des peptides issus de la thyrothricine extraite de Brevibacillus parabrevis

thyrothricine / tyrocidine / peptides antimicrobiens / activité antifongique / seuil de tolérance / Apis mellifera capensis

Toleranz von adulten und larvalen Honigbienen gegen Tyrothricinpeptide von Brevibacillus parabrevis

Tyrothricin / Tyrocidin / antimikrobielle Peptide / Landwirtschaft / Antimykotikum / Honigbienentoleranz

\section{REFERENCES}

Abbott W. S. (1925). A method of computing the effectiveness of an insecticide. J. Econ. Entomol. 18, 265-267.

Abel-Santos E. (2015). Modulating germination of Paenibacillus larvae. USA Patent Office US 14/ 578,091 .

Alvarez Z., Abel-Santos E. (2007). Potential use of inhibitors of bacteria spore germination in the prophylactic treatment of anthrax and Clostridium difficile -associated disease. Expert Rev. Anti Infect. Ther. 5, 783792.

Andersen O. S. (1984). Gramicidin channels. Annu. Rev. Physiol. 46, 531-548.

Asaka O., Shoda M. (1996). Biocontrol of Rhizoctonia solani damping-off of tomato with Bacillus subtilis RB14. Appl Environ Microbiol 62, 4081-4085.

Assie L. K., Deleu M., Arnaud L., Paquot M., Thonart P., Gaspar C., Haubruge E. (2002). Insecticide activity of surfactins and iturins from a biopesticide Bacillus subtilis cohn (S499 strain). Meded Rijksuniv Gent Fak Landbouwkd Toegep Biol Wet 67, 647-655.

Bailey L. (1957). The isolation and cultural characteristics of Streptococcus pluton and further observations on bacterium Eurydice. Microbiology 17, 39-48.

Beims H., Wittmann J., Bunk B., Sproer C., Rohde C., Gunther G., Rohde M., von der Ohe W., Steinert M. (2015). Paenibacillus larvae-directed bacteriophage HB10c2 and its application in American Foulbroodaffected honey bee larvae. Appl. Environ. Microbiol. 81, 5411-5419.

Broekaert W. F., Terras F. R. G., Cammue B. P. A., Vanderleyden J. (1990). An automated quantitative assay for fungal growth inhibition. FEMS Microbiol. Lett. 69, 55-59.

Chandel S., Allan E. J., Woodward S. (2010). Biological control of Fusarium oxysporum f. sp. lycopersici on tomato by Brevibacillus brevis. J. Phytopathol. 158, 470-478.

Che J., Liu B., Ruan C., Tang J., Huang D. (2015). Biocontrol of Lasiodiplodia theobromae, which causes black spot disease of harvested wax apple fruit, using a strain of Brevibacillus brevis FJAT-0809-GLX. Crop Prot. 67, 178-183.

Compant S., Duffy B., Nowak J., Clement C., Barka E. A. (2005). Use of plant growth-promoting bacteria for biocontrol of plant diseases: Principles, mechanisms of action, and future prospects. Appl. Environ. Microbiol. 71, 4951-4959.

Crailsheim K., Riessberger-Gallé U. (2001). Honey bee age-dependent resistance against American Foulbrood. Apidologie 32, 91-103.

Das K., Mukherjee A. K. (2006). Assessment of mosquito larvicidal potency of cyclic lipopeptides produced by Bacillus subtilis strains. Acta Trop. 97, 168.

Du Toit E. A., Rautenbach M. (2000). A sensitive standardised micro-gel well diffusion assay for the determination of antimicrobial activity. J. Microbiol Methods 42, 159-165.

Dubos R. J. (1939). Studies on a bactericidal agent extracted from a soil Bacillus: I. Preparation of the agent. Its activity in vitro. J. Exp. Med. 70, 1-10.

Dubos R. J., Cattaneo C. (1939). Studies on a bactericidal agent extracted from a soil Bacillus: III. Preparation and activity of a protein-free fraction. J. Exp. Med. 70, 249-256.

Dubos R. J., Hotchkiss R. D. (1941). The production of bactericidal substances by aerobic sporulating Bacilli . J Exp. Med. 73, 629-640.

EC-European Commission. (2010). Commission regulation (EU) no 37/2010 of 22 December 2009 on pharmacologically active substances and their classification regarding maximum residue limits in foodstuffs of animal origin. Off. J. Eur Union L 15, 1-72.

Elzen P., Westervelt D., Causey D., Rivera R., Baxter J., Feldlaufer M. (2002). Control of oxytetracyclineresistant American Foulbrood with tylosin and its 
toxicity to honey bees (Apis mellifera). J. Apic. Res. 41, 97-100.

Evans J. D. (2003). Diverse origins of tetracycline resistance in the honey bee bacterial pathogen Paenibacillus larvae. J. Invertebr. Pathol. 83, 46-50.

Foley K., Fazio G., Jensen A. B., Hughes W. O. H. (2012). Nutritional limitation and resistance to opportunistic Aspergillus parasites in honey bee larvae. J. Invertebr. Pathol. 111, 68-73.

Forsgren E. (2010). European Foulbrood in honey bees. J. Invertebr. Pathol. 103, S5-S9.

Genersch E. (2010). American Foulbrood in honeybees and its causative agent, Paenibacillus larvae. J. Invertebr. Pathol. 103, S10-S19.

Genersch E., Forsgren E., Pentikainen J., Ashiralieva A., Rauch S., Kilwinski J., Fries I. (2006). Reclassification of Paenibacillus larvae subsp. pulvifaciens and Paenibacillus larvae subsp. larvae as Paenibacillus larvae without subspecies differentiation. Int. J. Syst. Evol. Microbiol. 56, 501-511.

Ghribi D., Elleuch M., Abdelkefi L., Ellouze-Chaabouni S. (2012). Evaluation of larvicidal potency of Bacillus subtilis SPB1 biosurfactant against Ephestia kuehniella (Lepidoptera: Pyralidae) larvae and influence of abiotic factors on its insecticidal activity. J Stored Prod Res 48, 68.

Govan V. A., Allsopp M. H., Davison S. (1999). A PCR detection method for rapid identification of Paenibacillus larvae. Appl. Environ. Microbiol. 65, 2243-2245.

Guimarães A. B., Costa F. J. Q., Júnior O. R. P., Fontes W., Castro M. S. (2016). The amazing world of peptide engineering: The example of antimicrobial peptides from frogs and their analogues. Protein Pept Lett. 23, 722-737.

Hotchkiss R. D., Dubos R. J. (1941). The isolation of bactericidal substances from cultures of Bacillus brevis. J. Biol. Chem. 141, 155-162.

Kolmer J. A. \& Rule A. M. (1946). Toxicity and therapeutic activity of tyrothricin by oral administration. Proc. Soc. Exp. Biol. Med. 63, 315-317.

Krupke C. H., Hunt G. J., Eitzer B. D., Andino G., Given K. (2012). Multiple routes of pesticide exposure for honey bees living near agricultural fields. PLoS One 7 , e29268.

Lang C. \& Staiger C. (2016). Tyrothricin - an underrated agent for the treatment of bacterial skin infections and superficial wounds? Pharmazie 71, 299-305.

Lehrer R. I., Rosenman M., Harwig S. S. S. L., Jackson R., Eisenhauer P. (1991). Ultrasensitive assays for endogenous antimicrobial polypeptides. J. Immunol. Methods 137, 167-173.

Liou J., Hung Y., Yang C., Chen Y. (2015). The antimicrobial activity of gramicidin A is associated with hydroxyl radical formation. PloS One 10, e0117065.

Lüken D. J., Janke M., Lienau F., von der Ohe W., Forster R. (2012). Weiterentwicklung einer methode zur bienenbruthaltung unter laborbedingungen. J Verbrauch Lebensm 7, 141-145.
Maeda T., Takagi M., Imanaka T. (1993). Purification and characterization of a new metal protease which hydrolyzes the cyclic decapeptide, gramicidin S. J Ferment Bioeng 75, 173-177.

Mnif I., Ghribi D. (2015). Potential of bacterial derived biopesticides in pest management. Crop Prot 77, 52-64.

Mnif I., Elleuch M., Chaabouni S. E., Ghribi D. (2013). Bacillus subtilis SPB1 biosurfactant: Production optimization and insecticidal activity against the carob moth Ectomyelois ceratoniae. Crop Prot 50, 66-72.

Moncla B. J., Pryke K., Rohan L. C., Graebing P. W. (2011). Degradation of naturally occurring and engineered antimicrobial peptides by proteases. Adv Biosci Biotechnol 2, 404-408.

Montesinos E. (2007). Antimicrobial peptides and plant disease control. FEMS Microbiol Lett 270, 1-11.

Nautiyal C. S., Dion P. (2008). Molecular mechanisms of plant and microbe coexistence. Berlin Heidelberg: Springer.

Nickerson K. W., Schnell D. J. (1983). Toxicity of cyclic peptide antibiotics to larvae of Aedes aegypti. J. Invertebr. Pathol. 42, 407-409.

OECD (1998) Test No. 213: Honey bees, acute oral toxicity test: Organisation for Economic Co-operation and Development.

OECD (2013) Test No. 237: Honey bee (Apis mellifera) larval toxicity test, single exposure: Organisation for Economic Co-operation and Development.

Oldroyd B. P., Goodman R. D., Hornitzky M. A. Z., Chandler D. (1989). The effect on American Foulbrood of standard oxytetracycline hydrochloride treatments for the control of European Foulbrood of honeybees (Apis mellifera). Aust. J. Agric. Res. 40, 691-697.

Pettis J. S., Lichtenberg E. M., Andree M., Stitzinger J., Rose R., Vanengelsdorp D. (2013). Crop pollination exposes honey bees to pesticides which alters their susceptibility to the gut pathogen Nosema ceranae. PLoS One 8, e70182.

Pusey P. L. (1989). Use of Bacillus subtilis and related organisms as biofungicides. Pestic. Sci. 27, 133-140.

Pusey P. L., Wilson C. L. (1984). Postharvest biological control of stone fruit brown rot by Bacillus subtilis. Plant Dis. 68, 753-756.

Rammelkamp C. H., Weinstein L. (1942). Toxic effects of tyrothricin, gramicidin and tyrocidine. J. Infect. Dis. 71, 166-173.

Rautenbach, M., van Rensburg, W. (2015) Method for preventing or treating microbial growth on a manufactured product. PCT Patent Application PCT/ IB2015/054166.

Rautenbach M., Gerstner G. D., Vlok N. M., Kulenkampff J., Westerhoff H. V. (2006). Analyses of dose-response curves to compare the antimicrobial activity of model cationic alpha-helical peptides highlights the necessity for a minimum of two activity parameters. Anal Biochem. 350, 81-90. 
Rautenbach, M., Troskie, A.M., De Beer, A., Vosloo, J.A. (2013) Antimicrobial peptide formulations for plants. WO/2013/150394 A1.

Rautenbach M., Vosloo J. A., Van Rensburg W., Engelbrecht Y. (2015). Natural antimicrobial peptides as green microbicides in agriculture: A proof of concept study on the tyrocidines from soil bacteria. Gree Economy Research Report, Green Fund, Development Bank of Southern Africa, Midrand.

Rautenbach M., Troskie A. M., Vosloo J. A. (2016a). Antifungal peptides: To be or not to be membrane active. Biochimie 130. 132-145.

Rautenbach M., Troskie A. M., Vosloo J. A., Dathe M. (2016b). Antifungal membranolytic activity of the tyrocidines against filamentous plant fungi. Biochimie 130, 122-131.

Reybroeck W., Daeseleire E., De Brabander H. F., Herman L. (2012). Antimicrobials in beekeeping. Vet. Microbiol. 158, 1-11.

Robinson H. J., Molitor H. (1942). Some toxicological and pharmacological properties of gramicidin, tyrocidine and tyrothricin. J. Pharmacol. Exp. Ther. 74, 75-82.

Schobert C., Köckenberger W., Komor E. (1988). Uptake of amino acids by plants from the soil: A comparative study with castor bean seedlings grown under natural and axenic soil conditions. Plant Soil 109, 181-188.

de Souza R., Ambrosini A., Passaglia L. M. P. (2015). Plant growth-promoting bacteria as inoculants in agricultural soils. Genet. Mol. Biol. 38, 401-419.

Spathelf B. M., Rautenbach M. (2009). Anti-Listerial activity and structure-activity relationships of the six major tyrocidines, cyclic decapeptides from Bacillus aneurinolyticus . Bioorg. Med. Chem. 17, 5541-5548.

Spivak M. (2000). Preventative antibiotic treatments for honey bee colonies. Am. Bee J. 140, 867-868.

Stauss-Grabo M., Atiye S., Le T., Kretschmar M. (2014). Decade-long use of the antimicrobial peptide combination tyrothricin does not pose a major risk of acquired resistance with gram-positive bacteria and Candida spp. Pharmazie 69, 838-841.

Tang X. J., Thibault P., Boyd R. K. (1992). Characterization of the tyrocidine and gramicidin fractions of the tyrothricin complex from Bacillus brevis using liquid chromatography and mass spectrometry. Int. J. Mass Spectrom Ion Processes 122, 153-179.

Troskie A. M., Vlok N. M., Rautenbach M. (2012). A novel 96-well gel-based assay for determining antifungal activity against filamentous fungi. J. Microbiol. Methods 91, 551-558.

Troskie A. M., de Beer A., Vosloo J. A., Jacobs K., Rautenbach M. (2014a). Inhibition of agronomically relevant fungal phytopathogens by tyrocidines, cyclic antimicrobial peptides isolated from Bacillus aneurinolyticus . Microbiology 160, 2089-2101.

Troskie A. M., Rautenbach M., Delattin N., Vosloo J. A., Dathe M., Cammue B. P., Thevissen K. (2014b). Synergistic activity of the tyrocidines, antimicrobial cyclodecapeptides from Bacillus aneurinolyticus, with amphotericin B and caspofungin against Candida albicans biofilms. Antimicrob. Agents Chemother. 58, 3697-3707.

Vosloo J. A., Stander M. A., Leussa A. N. N., Spathelf B. M., Rautenbach M. (2013). Manipulation of the tyrothricin production profile of Bacillus aneurinolyticus . Microbiology (United Kingdom) 159, 2200-2211.

Wang S., Zeng X., Yang Q., Qiao S. (2016) Antimicrobial peptides as potential alternatives to antibiotics in food animal industry. Int. J. Mol. Sci. 17 E603.

Weinstein L. \& Rammelkamp C. H. (1941). A study of the effect of gramicidin administered by the oral route. Exp. Biol. Med. 48, 147-149.

Yue D., Nordhoff M., Wieler L. H., Genersch E. (2008). Fluorescence in situ hybridization (FISH) analysis of the interactions between honeybee larvae and Paenibacillus larvae, the causative agent of American Foulbrood of honeybees (Apis mellifera). Environ. Microbiol. 10, 1612-1620. 